\title{
The -ography of markets (or, the responsibilities of market studies)
}

Philip Roscoe and Olga Loza, University of St Andrews

pjr10@st-andrews.ac.uk

ol6@st-andrews.ac.uk

\section{Abstract}

How should we write about markets? What responsibilities does this writing bring upon us? This paper offers an immanent critique of 'market studies' scholarship, and through this a call to reflection and reformed action. Turning the intellectual framework of market studies upon itself, we come to see its texts as performative and agential. We discuss these qualities and the associated responsibilities via a reading of literature from the domain of ethnography. An auto-ethnographic sketch of market writing allows us to consider the problematic nature of expertise for market studies scholars and the agency and power of our texts. We find a dual moment of performativity from which our texts emerge more powerful than their authors. On this basis we offer a vision of critical interventions embedded in our texts, underpinned by the intellectual axioms of the market studies program.

Keywords

Market studies, ethnography, critical perspectives, performativity, texts, power relations

\section{Acknowledgements}

Early versions of this paper were presented at the $15^{\text {th }}$ Annual Ethnography Symposium, Manchester, August 2017, and the $5^{\text {th }}$ Interdisciplinary Market Studies Workshop, Copenhagen, June 2018. The authors would like to thank all present on both occasions for their contributions, notably Lisa Knoll, Neil Pollock, and Koray Çalışkan. We would also like to thank Taylor Nelms, editor of Journal of Cultural Economy, and two anonymous reviewers for their generous comments and sound judgement. Errors and omissions remain the responsibility of the authors alone. 


\section{The-ography of markets (or, the responsibilities of market studies)}

How should we write about markets? What do our texts do, and what responsibilities does this 'marketography' (Neyland and Ehrenstein 2017) bring upon us? This paper offers a challenge to our field: a call to critical reflection and reformed action.

As we offer a provocation to a field we would do well to define it early on. It stems from the encounter of science studies with the disciplines of economic sociology and anthropology (Çalışkan and Callon 2009). We may date its inception to Callon's introductory chapter in The Laws of the Markets (1998) with its injunction to study the socio-technical construction of the economy. Callon's formulation of the 'performativity thesis' was taken up by many, most prominently by MacKenzie (2006) and his colleagues (e.g. MacKenzie and Millo 2003, MacKenzie et al. 2007). MacKenzie (2009) went on to sketch out precepts for a 'social studies of finance', while Çalışkan and Callon (2010, p. 3) proposed a research programme focused on the empirical phenomenon of 'marketization'. Here a market is a socio-technical assemblage that organises the conception, production and circulation of goods: 'an arrangement of heterogeneous constituents that deploys...rules and conventions, technical devices, metrological systems, infrastructures, text, discourses', among other things. The ongoing disciplinary encounter rapidly spilled into marketing (Araujo et al. 2010, Cochoy 2015), the novel field of valuation studies (Muniesa 2011, Helgesson and Muniesa 2013), and more recently organisation studies (Roscoe and Chillas 2014, Geiger and Gross 2018, Palo et al. 2018). It is, therefore, a heterogeneous literature but one that is united by common theoretical concerns: the constructed nature of markets and market knowledge, theories of performativity and qualification, an emphasis on the material embeddedness of markets and market action, on expertise and on evaluation. Our greatest difficulty, perhaps, is knowing what to call this genre. We could choose 'economisation' or 'marketisation' (Çalışkan and Callon 2010), or the 'social studies of markets', following MacKenzie. When we write about markets we do 'marketography' (Neyland and Ehrenstein 2017), while McFall and Ossandón (2014) propose 'the new, new economic sociology'. But for this paper we prefer a simple, collective coinage: market studies.

Market studies has not grown uncontested. It has been critiqued by scholars with interests in classical political economy (Christophers 2014), who invoke power, class, and capital, or in 'cultural economy' (Du Gay and Pryke 2002), emphasising the role of language and discourse in demarcating and structuring markets (e.g. Poovey 2008, Preda 2009, Bryan and 
Rafferty 2015). Although these literatures may find a common readership in the Journal of Cultural Economy, the differences can be stark: where political economy distances the clearsighted critical scholar from the collective false-consciousness of market agents (e.g. Shonkwiler and La Berge 2014), market studies emphasises the ability of descriptive analysis of market agencements to unpack power relations in the institutions of high modernity (Beunza and Ferraro 2018). Power relations are embedded in differentials of calculative ability (Callon and Muniesa 2005) and examples abound of scholars depicting the assemblages of power that underpin markets. Such descriptions are predicated on the field's openness to empirical observation - an openness that is itself underpinned by agnosticism as to the nature of actors implicated in the observed situations, the abandonment of a priori distinctions, and a commitment to symmetrical explanation of various phenomena (Callon, 1986). It is this very openness that perturbs the political economist: rejecting a notion of the economy as a coherent whole makes impossible any account of structural power relations within such a system. Instead, as Nik-Khah and Mirowski (2007) argue, performativity narratives construct a kind of victor's history that overemphasises the work of economic theory at the expense of structural explanations and organizational happenstance.

These critiques are slowly being answered, with scholars beginning to develop a hybrid 'material political economy' (MacKenzie 2017). Nonetheless, there is more to be done, and we have taken up the neologism 'marketography' (Neyland and Ehrenstein 2017) to help us navigate some of the issues at stake. 'Marketography' not only describes what we do writing about markets - but also provokes us to reflect critically upon our practice and to subject it to the same questions that ethnographers have asked of their own work. For ethnographers have recognised that ethnography can never be wholly 'innocent', and that ethnographic description is itself a form of writing, relying on our ability to translate our observations into words assembled in articles, books and reports (Denzin 2006, p. 422). Social science texts fix the unstable and inchoate in time and space, ascribing to it particular meanings, fleshing out and elaborating the phenomena they describe (Law and Urry 2004); our 'marketography' is necessarily a performative, 'constitutive practice' (Haraway 1988, p. 312). So we must agree with the political economists, at least in part. We are complicit in enacting particular versions of markets while obscuring, or even eroding, others. In this light, our choice of the word 'marketography' becomes both a political act and a provocation. The word itself encourages us to turn our analytical principles - in particular, the performativity thesis, the intellectual engine driving so much of our work - upon ourselves. When we do so, 
following through on our own axiom of methodological symmetry, we will begin to consider the work that our texts might do in the field as actors in their own right. A clearer recognition of the performative nature of market studies research will, we suggest, offer new visions for critical engagement and emancipatory scholarship in our field. If our central claim is that market knowledge is performative - that it participates in bringing markets into being - and if economics offers just one kind of market knowledge, it follows that the economists' markets - the markets of high modernity — are just one kind of market, and there are as many others possible as we can conjure in our writing.

We suspect that many in the field share political sensibilities, and that the study of 'marketization' (Çalışkan and Callon 2010) is often motivated by a desire to problematize an increasingly hegemonic organisational form; Boldyrev and Svetlova $(2016$, p. 10) speak of the critical task confronting scholars of performativity as being 'to reveal the genealogy of economization, to stop treating particular social structures as pre-given...sometimes, to reveal a hypocrisy of certain practices'. Critical management scholars see a 'critical performativity' as 'specific and focused attempts to create spaces of autonomy among institutionalized relations of power' (Spicer et al. 2009, p. 553). Thus Frankel et al. (2015) propose a move - a translation - to studying markets as policy devices and the knowledge employed to support this endeavour. We argue, however, that we should be reflexively aware of the productive capacities of our own knowledge. Recognizing the performative power of our own scholarship makes possible a second emancipation: of our texts and of our imagination, freeing our writing from the received assumptions that restrict the worlds that we might document and the futures we might perform. It is a call to ambition and daring in our scholarship, and brings with it a responsibility to seek change through our work; not only to document the assemblages of actually existing markets but also to write the markets of the future, markets at the limits of the possible.

We argue in this paper that we can engage with, and even mobilise, the performativity of our own writing to re-imagine and re-tell markets. We acknowledge a growing 'performative turn' (Gond et al. 2015) in organization studies, which has suggested that performativity could link academic work and managerial practice, and thus revive the tired debate between rigour and relevance. While we agree, we outline a possibility of a more transformative engagement. Following work elsewhere in the social sciences (e.g. Safri 2015, Braun and Könninger 2017) we advocate an participatory, action-based critique of markets that 
mobilises the agency of our texts: an engagement with practice, a creative retelling of the possibilities of markets, a reworking of the narratives that economics has spent so long constructing (Hirschman 1977, Cochoy et al. 2010). It is a call for work on the margins of markets: among actors exploring novel forms of exchange, in literature and fantasy, in digital worlds and ones alien to the markets of high modernity. It is a call for discourse and engagement with participants, for new kinds of texts and for writing that can transcend the seminar room. We acknowledge that not everyone may share our sensibilities, and we also take note of the frequent cautions offered by existing literature concerning the difficulty and complexity of effective participatory research (Blackstock et al. 2015): ours, then, is an uncertain endeavour - made more so by the economisation of our own profession - and yet we believe it is one worth pursuing.

Although our provocation is offered to the collective field, any action is likely to be local and often individual. The paper offers an auto-ethnographic turn on the part of the first author as an example of such action-based critique, charting his research into smaller company stock markets and reflecting on its potential as a participatory moment in novel financial arrangements. It highlights the possibilities open to us as well as the contradictions and risks we face in trying to move our scholarship out of the seminar room. We begin, however, by discussing the performative power of market-writing and drawing on the parallel methodological discussions among ethnographers to illuminate some of the challenges - and possibilities - that it presents.

\section{Performativity in market studies}

Market studies investigate actually existing markets as 'organized collective devices' and the way in which market relations 'depend on a particular architecture of exchange' (Callon and Muniesa 2005, p. 1240). The architectural metaphor evokes the concerted efforts of multiple heterogeneous agencies required to bring into being and uphold any market. Agents and goods must be disentangled from other relations and framed, or defined, as entities capable of forming market attachments and of circulating in the market (Callon, 1998). Moreover, the metaphor is useful in foregrounding the crucial role of material artefacts - objects, tools, technologies - in configuring markets. From this perspective, markets are socio-technical agencements: 'the assemblages or arrangements - which are simultaneously human and 
nonhuman, social and technical, textual and material - from which action springs' (MacKenzie et al. 2007, pp. 14-15).

Such is the central preoccupation of market studies, to produce detailed descriptions of how markets come into being, and of the efforts and investments required to sustain them. The performativity thesis (Callon 1998) offers a theoretical programme to support this endeavour: it recognizes that markets are shaped by knowledge, whether lay, practitioner or academic. Since Callon's seminal contributions in The Laws of the Markets, scholars have demonstrated that the existence of the market as an abstract entity is the outcome of 'efforts in abstraction' performed by economics (Callon and Muniesa 2005, p. 1244). Economic knowledge theoretical as well as practical, codified in disciplines like accounting and marketing participates 'in the design, elaboration, experimentation, change, maintenance, extension and operation' of markets (Çalışkan and Callon 2010, p. 23). Economics, then, can no longer be considered an 'objective' science that captures a pre-existing state of affairs. Instead, we recognise that it draws on multiple instruments and practices to participate in 'performing' the economy and the market, 'creating the phenomena it describes' (MacKenzie and Millo 2003, p. 108).

The notion of performativity originates in the work of the philosopher of language J.L. Austin. For Austin, performative utterances are those 'in which to say something is to do something; or in which by saying or in saying something we are doing something' (Austin 1978, p. 12, italics in original). However, as Butler (2010, p. 150) notes, performative power resides not so much in the subject issuing the statement as in 'the mundane and repeated acts of delimitation' and in the constantly renewing sets of relations and practices that fuse human and non-human domains. Callon's (2007) notion of 'co-performation' similarly helps to capture performativity as a material, collective, heterogeneous practice riddled with 'conflicts, upsets, crises, and competition' rather than as 'just a property of statements' (MacKenzie et al. 2007, p. 15). In market studies scholars' work this processual and distributed understanding of performativity has resulted in the recent years in what Boldyrev and Svetlova (2016, p. 2, italics in original) term the 'drift toward investigations of performative practices'. Markets comprise multiple socio-technical elements, certainly, but exist because those elements are configured to make markets thinkable and possible. Paralleling Butler's (2010, p. 147) assertion that the economy 'only becomes singular and monolithic by virtue of the convergence of certain kinds of processes and practices that 
produce the 'effect' of the knowable and unified economy', market studies show that 'the market' - designated as a universal, abstract medium of exchange, and stripped of all local meanings attached to it in particular settings - is constituted and solidified as an object of knowledge through distributed and iterative practices that treat it as such.

Conceived as an iterative and heterogeneous practice, performativity is a useful concept in thinking through what our own work - as market studies scholars - entails. Indeed, Butler's outline of the critical-emancipatory potential of performativity invokes the goals and efforts of much market studies research:

first, that performativity seeks to counter a certain kind of positivism according to which we might begin with already delimited understandings of what gender, the state, and the economy are. Secondly, performativity works, when it works, to counter a certain metaphysical presumption about culturally constructed categories and to draw our attention to the diverse mechanisms of that construction. Thirdly, performativity starts to describe a set of processes that produce ontological effects, that is, that work to bring into being certain kinds of realities or, fourthly, that lead to certain kinds of socially binding consequences. (Butler, 2010: 147)

In view of the socially binding consequences and ontological effects of performativity, it is surprising that market studies scholars pay little attention to the performativity of our own research. If we want to argue that representations are always interventions we must admit that our accounts of markets are never innocent: they always participate in the co-performation of the market. They do so in multiple diverse and often conflicting ways. Codified in journal articles and reports, theories, formulas, and techniques, but also circulated in the form of practitioner recommendations, personal communications, and even gossip and word-ofmouth, they can ossify, as well as disrupt, conventional and hegemonic understandings of the markets. Consequently, market studies can - and often do - contribute to reconfiguring the markets under our study. Similar concerns regarding the possible real-life consequences of their work have for decades animated ethnographers working in other disciplines, from anthropology to political science and sociology. To better understand the possible ramifications of market studies research - the ways in which it might be performative - we therefore now turn to ethnographers' discussions of the effects and consequences of their work. 


\section{Writing ethnographies of markets}

Market studies texts are not transparent and unproblematic representations of reality, but outcomes of practical efforts, of empirical work, of 'marketography' (Neyland and Ehrenstein 2017). If we follow the line of reasoning that the neologism suggests, we can infer that marketography entails an ethnographic commitment to participation and close observation (Hine 2000, Neyland 2008, Watson 2011) as a means to an in-depth engagement with, and understanding of, the markets. Market studies' goal of denaturalising the market mirrors ethnography's refusal to take for granted what goes on in the field. Indeed, 'making strange' the familiar in order to 'see the world with fresh vision' (Van Maanen 1988, p. 127) has historically been the goal of ethnography as a method. Organisational ethnographies, in particular, have tried to foreground the counter-intuitive aspects of organisational activities through scrupulous, detailed investigations:

Getting close to the organizational action is not just about telling the audience what they already know but also involves a refusal to take anything for granted. In the same way that anthropologists encountered exotic locations, tribes and customs, the organizational ethnographer can shift the everyday into the exotic, by carrying out detailed and close examination of their subject matter. (Neyland 2015, p. 6)

This is a political endeavour, and ethnography, as Denzin (2006, p. 422) put it, 'is not an innocent practice.' More than any other method, ethnography forces us to confront the question of how we, as researchers, are implicated in the social worlds we study (Pachirat 2018). If it is 'in, while, and through writing' that we work out our ideas (Yanow 2009, p. 278), we need to be particularly attentive to the performative potential of our writing. Ethnographies are 'written and unavoidably constructed accounts of objects created through disciplinary practices and the ethnographers' embodied and reflexive engagement' (Hine 2000, p. 42), 'messy texts' (Cunliffe 2010, p. 231) that can capture only some aspects of the researcher's experience in the field. As such, they are always selective, always incomplete. This is an unavoidable consequence of representing lived experience in writing, 'a constructive act rather than a straightforward reflection of reality' (Hine 2000, p. 56) because of the disciplinary, narrative, cultural, institutional, and historical processes implicated in the writing of ethnographic texts. 
That ethnographic fieldwork is necessarily selective is a widely accepted constraint, for it requires the researcher to establish boundaries of what is to be observed and studied. In carving out the field site as a 'manageable unit' (Clifford 1992, p. 98), the researcher relies on her understanding of what the phenomenon under investigation is, where it takes place, and who the relevant actors may be. Marketographers are particularly cautious about this necessary selectivity, for one of their main theoretical preoccupations is to not take for granted the assumed boundaries of markets, but instead to trace the movements of, connections between, and configurations of market-making agencements across different times and places. We are always caught up in tension between the temptation to capture all aspects of market agencements, yielding indiscriminate, trivial descriptions (Hardie and MacKenzie 2007) and the possibility that a more selective focus will foreclose and obscure crucial aspects of the markets we study.

Ethnography not only demarcates its sites but also constitutes their occupants; the subjects of ethnographic research can never precede the doing of that research. Ethnographers call their subjects into being and fix them in place, freezing 'both in time and as established knowledge, a particular moment in a broader and more fluid series of power relations and identity constructions' (Pachirat 2018, p. 45). We might worry, perhaps, that market studies runs the risk of calcifying the boundaries of the economic, becoming itself a handmaiden of economic theory: this has been the substance of many critiques of performativity (Christophers 2014). If we take seriously Frankel's (2015) observation that there are in any given context and at any given time multiple competing notions of markets operating at once - what Mol (2002: 164) calls 'the permanent possibility of alternative configurations' - we must seriously consider how our writing stabilises, sediments, and reifies particular versions or aspects of those markets. We marketographers are necessarily complicit in enacting particular versions of markets while obscuring, or even eroding, others: if there are multiple markets, fixing one in writing precludes others from coming into being. Once we are reflexively aware of this 'normative horizon' (Butler 2010, p. 150) of performativity, we might subject our work to more thorough examination in terms of the political projects in which our writing is, or can be, enrolled. If we accept performativity as the ongoing and iterative process of enactment of realities, at once discursive and material, we begin to ask with (with Butler 2010, p. 152) not only 'how things are made,' but also, and crucially: 'How are we to join in the making of what is already underway?' 


\section{An auto-ethnography of a marketography}

How might we join in the making of what is already underway? We seek to answer this through a reflexive excursus, turning our methodological tools back upon ourselves. We propose a methodological symmetry, treating our own texts as powerful actors or 'market devices' (Callon et al. 2007) capable of travelling through networks and enrolling assemblies of their own.

In 2016 the first author (now 'I') secured funding to research "a historical sociology" echoing MacKenzie and Millo (2003) - of two smaller company stock markets founded in London in the 1990s. There is a backstory here: in my twenties I was a stocks and shares journalist during the frothy years of the dot-com boom and I came to know these markets and their constituents well. I began with an intuition that something happened in the mid-to late 1990s, something sociologically interesting, and something politically relevant. Over the next 18 months I untangled the narratives of these markets and unearthed a complex story of regulatory overflow, competitive rivalry between exchanges, of damaged pride and unfortunate endings. These are rich data, the stuff of which market studies is made. They show, among other things, how powerful market actors maintain their advantages across a rapidly changing landscape of markets, how the tools and mechanisms of markets bring with them their own distinctive ethics of office, and how these markets are structured by forms of organisation quite alien to the efficient market hypothesis framing of much contemporary finance. But I also discovered among the personal projects of interviewees a critical agenda of a sort: a genuine concern for the role of junior stock markets as mechanisms of wealth enhancement and distribution and a continued openness to new ideas and possibilities on this front.

Although many interviews started, 'I am glad you used to work in the city, because you'll understand what I have to say,' the words that followed still sounded strange. I had what Goodall (2010) terms 'perspective by incongruity'. As an academic at least partially sensitised to issues of gender I noticed just how masculine a world this part of finance was. Language was visceral and bodily, metaphors pungent. It became clear early on that the most significant player on the entire stage was female, and yet that person was slow to agree to an interview. Instead I had multiple narratives from men seeking, in different ways, to position 
themselves as at least equivalent in terms of their contribution to the new markets. I was eventually able to meet her twice, and to reinstate her in the centre of the story. But I am certain that for this one inclusion there are other contributions excised, and other stories overlooked. My account is bounded in time, in social and material space, and also in the relations of power that suffuse the field, explicit or otherwise.

The campaign for academic publications continues, of course. But I also wrote a narrative account of the history of these markets, aimed largely at a practitioner audience. In part, I wrote it simply to get hold of a dataset spiralling out of control. When I had finished the draft I circulated it among the interviewees, wondering if anyone would like to talk further. Many did, and I spent a busy week in London meeting my sources. I found this surprising. I was surprised that a retired businessman worth many tens of millions of pounds would take time to plough through my report and pick up on small points; that senior executives would take the time to gently persuade me that my emphasis was wrong, or that I was mistaken on key points. In fact, I was surprised that anyone cared about the work of an obscure mid-career academic. I should not have been: paraphrasing Van Maanen's (1988) opening line, marketographic work carries serious intellectual and moral responsibilities, for the images of others inscribed in writing are most assuredly not neutral.

The report was published soon after (Roscoe, 2017), the printing paid by an industry body that wished to remain nameless. By that act the report was instantly enrolled in a circuit of political relations. I made it available online so that it can be freely downloaded. I get the occasional email from someone in the market, or someone to whom the piece has been recommended as the go-to history of the sector. I was invited to an industry forum to speak to corporate financiers collecting professional development points during their lunch hour; there is talk - I am told - of my findings appearing on an exam syllabus. Everyone is very complimentary. I am clearly the expert on the topic, but being the expert is not unproblematic.

This positioning of expertise makes me feel uncomfortable. One great strength of economics over the last fifty years is that it has been able to provide the 'real world' with positive 'answers' - scare quotes round both - from free markets as the answer to totalitarianism, to diagnoses of irrationality as means of managing the atavistic biases of the hoi polloi. It is exactly that paternalism, a manifestation of the demarcation of expert observer from the matter under investigation, that our understanding of performativity seeks to overcome: 
economics is, after all, a discipline that thoroughly constitutes the worlds it describes (Roscoe 2014). A market studies scholar might reasonably eschew such a blunt attribution of expertise, but it is hard to avoid, for the conventions of narrative construction have their own performative consequences. Late at night I had put some half-thought-out conclusions onto the end of the report, and I now repurposed these into an 'executive summary' in keeping with the genre of a practice-focused report. For example, I write that 'The history of the UK's smaller company stock markets shows an ongoing, though cyclical, demand for growth funding and share trading mechanisms (on the part of companies) and investment opportunities.' Where some social scientists might produce longitudinal statistics to support such an assertion, I know this through the methods that market studies places at our disposal: interview, observation, documentary work, generalisation from the historical record. I know because I have asked experts and they have told me. Therein lies a whole association of claims about expertise, the status of academics versus practitioners, and the social construction of knowledge. We know these arguments well, recognizing that different kinds of empirical work substantiate different knowledge claims, but the report's very form does away with such subtleties, leaving me intellectually exposed and internally uncomfortable. How reflexively provoking the act of being an expert turns out to be! To position oneself in the public discourse in such a way is to be 'an economist', and not only in the Callonian sense of someone who knows about markets; the audience of practitioners does not distinguish much between someone who knows economics as 'a sociologist' and someone who does economics. The very first act of communicating findings to a practitioner audience, then, seems to be one of 'betrayal' (Deville 2017) of market studies itself.

The recommendation-conclusions might seem banal to the scholar of markets. I point out that the shape of these markets is embedded in particular social and organisational cultures and material path dependencies, for example, or that relying on social networks formed in the preBig Bang era as the main regulatory mechanism has become problematic three decades on. Yet, these claims seem to carry some weight, precisely because my observations are contextually specific and situated. I'm talking about their world in ways that participants find novel and illuminating. I also have to accept that much of the intellectual and analytic purchase of my marketography does come from its institutional setting and intellectual context; I may be an obscure specialist researcher, but I'm also a reader at the University of St Andrews, and that in itself seems to provoke, in London at least, a particular and peculiar set of cultural semiotics. 
Still, I am troubled as to what I wish to achieve, or, rather, what I feel I can say. I find myself talking about entrepreneurial ecosystems, but I suspect that's too easy: a single slip to the econ-lite prescriptions of the opinion column. Without the positivist's certainty of a simple rule (Friedman 1966) the work of translating or retelling seems perilous. But we marketographers must know something.

What can I say? More precisely, what do I know? Let me give a small example. Over the last few years, my interest as a management researcher has fastened on the moral codes embedded in and performed by market structures: from organ allocations (Roscoe, 2015) to rational calculative romances, for example (Roscoe and Chillas, 2014). In the current project it is quite clear that different kinds of market mechanisms bring into being different moral economies of office, to use a Weberian vocabulary (du Gay 2008). In fact, conflicts between these rival ethics are one of the great sources of strife and change within the sector. The finding came strongly from the data, with many individuals talking about their responsibilities and moral codes: we did 'what was right for the market', says one, before criticising the actions of another, who subsequently gave me a long justification in a frame of reference that any MBA would recognise.

When I began to draft an earlier version of the present paper, I realized that I had not included the finding in my report's summary. Perhaps it did not feel applied enough, or useful enough. But that's absurd, because - in view of the kind of knowledge I have - the things I judge as useful are most likely things that the practitioners know far better than me already; the sole value I can add is by pointing out things to those in the market that they might never otherwise have seen, in this case because they have never read Max Weber. Market studies here must function like a mirror, illuminating its image with theoretical insight and a little, judicious magnification. Posturing as expert I struggle with the disjuncture between the professional reserve of the marketographer, insisting upon the situated specificity of actually existing markets, and the need for straightforward, generally applicable solutions to market problems. But our expertise is that of the engaged counsellor rather than the dispassionate scientist and it is embedded in our texts; it took the self-consciously reflexive act of drafting this paper to allow me to think through the nuances of what it means to be both a scholar and an expert.

So much for expertise. What of actors? As marketographers we are methodologically charged with following the actors (Latour 2007) as they travel through the networks of the 
markets. The actors here are the expert - your first author - and his report, independently mobile and separately efficacious. In terms of the first, I am being pulled slowly into the community. I have sat in bars with brokers. I attended the boozy wake of a legendary PR man and a grand dinner at the Dorchester. My political antennae have become sharper, and I am starting to recognise the divisions and struggles between the practitioners themselves. Yet I am an outsider, too. It was clear that certain individuals saw my document as a means to a particular end. The hastily written draft conclusions turned up at the London Stock Exchange at the end of a long email string, despite the fact that I had specifically requested that the report should not be circulated. A well regarded but cantankerous newspaper columnist known for his fondness of free markets asked, via a third party, 'what point is he making for the future that would make this relevant for today's audience?' The question took me by surprise until I remembered my new-found 'expertise', with the need for currency and soundbite it implies.

My report travelled into the hands of another group, seeking to set up a regionally focused stock exchange to deliver 'social impact investing'. The recommendations that appeal to this group are different. I write that 'The perspective of British enterprise - an important political and rhetorical motif in this story - demands mechanisms to reinvigorate issuer activity in Scotland, Wales and the English regions. Growing infrastructure costs and associated economies of scale suggest that 'white label' services offered by large providers may be a more effective solution than de novo start-ups...' and that 'my study also shows that stock markets are simply talked into being. Infrastructure, an appropriate regulatory environment and underlying demand are necessary but not sufficient conditions for the successful formation of a market.'

Once again, these claims seem to carry weight. There is a power in articulating these things, even if actors intuitively know them already, as they must, for me to have discerned these matters in their transcripts. Market knowledge is performative, and to write about markets is to reconstruct them as we do so. If I write of novel markets capable of reinvigorating regional economic activity, so I make them a possibility; if that writing can enrol sufficient actors, those markets might become an actuality. The text has landed on the desk of politicians and business influencers, and there is an opportunity to shift policy and to effect change in the policy slipstream of the vaunted new Scottish national investment bank. Alas, it does not seem to be an opportunity for me, for here the trail goes cold. The text can visit places I 
cannot. I am jockeying for position on an advisory board, if such a thing ever comes about, and that might grant me access once more. But advisory boards are filled with experts, and again I wonder whether this is a legitimate step for the marketographer, whose detailed, situated account almost resists application. But to focus on the first author's interactions is to miss our central point. For it is already becoming clear that the author has done something in giving rise to the text, and that the text is agency-filled and capable.

\section{Discussion: When texts are stronger than their authors}

There is lively and long established tradition of participatory research within the social sciences. Underpinned by a commitment to social transformation via the removal of power asymmetries, participatory research can be characterised as a 'performative ontological project' (Safri 2015). While participation is often understood as interpersonal and active, our vision of engagement is one driven by narratives - the -ographies of markets. We have outlined an immanent critique of market studies literature as a call for an imaginative retelling of market possibilities. Our demand for methodological symmetry requires us to recognise the agency and performativity of our texts. When we do this, we recognise that our marketography enjoys a double moment of performativity. Market ethnographies, like all social science texts, co-produce the worlds they ostensibly only describe. This is the first performative moment. Studies of markets frame their objects in certain ways, fixing relations of power and naturalizing some assumptions just as they undo others. The second performative moment lies in the possibility of our texts becoming enrolled in the very networks they describe and reconfiguring social worlds as they do so. These moments are linked: how the texts frame the phenomena under study will determine their capacity to travel through and transform social worlds. So we should be concerned with the 'ontological politics' of market-writing: 'a politics that has to do with the way in which problems are framed, bodies are shaped, and lives are pushed and pulled into one shape or another' (Mol 2002, p. viii). We have indeed seen calls for such responsible engagement, but they often remain tentative: gentle suggestions appended in conclusion of articles reckoning with the nature of our distinct kind of sociology. McFall and Ossandón (2014, p. 526), for instance, call upon scholars

to engage seriously with the development of calculative practices and with how the 
products of the academy, all those techniques, knowledges, and tools, play their roles in the formation of markets and market relations,

while Ossandón (2014) moves again to expand the theoretical basis of market studies, developing an analytic framing that incorporates theories of property and rights from elsewhere in the social sciences. These authors recognize the performative nature of our own knowledge and the responsibilities that brings, asking what our writing does in the world. We push further, and wonder what it might do: if market knowledge is performative, and the markets of late modernity are the result of economic writing, there are as many other markets possible as we can conjure with our texts. Our provocation is a call for imagination in our scholarship and for work on the margins of - even beyond - markets. It is a call for discourse and engagement with participants, for texts and for writing that can transcend the seminar room.

The first author's reflexive engagement with the text produced as a result of his ethnographic work in the smaller company stock markets in London begins to sketch out just what we mean by 'owning up to' our responsibilities as researchers and 'engaging seriously' with the 'products of the academy'. The author wrestles with his text and loses. A narrative of markets written for a practitioner audience (in this example) is bound by its own conventions and enacts novel performances of its own. The author felt compelled to add summary recommendations to the front of the document, an echo of the 'executive summary' attached to practice reports as a matter of course. Even the words chosen reflect the narrative's own agency: avoiding academic terminology at time provokes lengthy periphrasis, while at others directs the author to a sharp, unexpected point.

The author, at least the author qua 'expert', can travel through networks, although this is time-consuming, costly work. The text meanwhile can circulate on its own account, making alliances, enrolling others into its network. We suggest that the text is by far the more powerful actor: more mobile, more versatile, more able to co-opt and be co-opted into networks of association. As our theoretical survey suggests, the second moment of performativity is linked to the text, not the author. The malleability of the text and the ease with which it may be swept up and enrolled in the projects of others, its fluidity of travel and its availability to offer support wherever it is needed, makes it a far more attractive partner than the lumpen physicality and contrary agency of the man who wrote it. When he steps into a network, it is likely that the text is there already; that it has been enrolled in pursuit of a 
specific project and once fixed in place, invites its author along too. Where egos clash over the meeting table, the text remains unperturbed; the text is sweeter, smoother, and far more successful.

Yet a text cannot be separated from its author, whose politics and prejudices it inevitably reflects. Once we recognise this and, as Law and Urry (2004) propose, abandon claims to innocence and objectivity in favour of active, political engagement, perhaps our marketographies can produce 'not effects of distance, but effects of connection, of embodiment, and of responsibility' (Haraway 1992, p. 295) and 'generate productive uncertainties and disjunctive possibilities for social engagement' (Battaglia 1999, p. 114). Our goal is not to offer a universal grammar of market action, long the aim of economics, but to write critical interventions, often in partnership with stakeholders and research participants. If new markets are to be written into being, the more affordances a text can offer, the better; we marketographers must balance between accessibility, mobility, and solid, sturdy intellectual discipline.

This is a pragmatic response: if marketography is performative, we should attempt to put its performativity to good use; if the accounts we produce can participate in re-configuring the world that we inhabit, we have to make sure that those accounts are relevant and useful. We are certainly not the first in our field to draw attention to the possibility of our work envisioning new futures. Çalışkan and Callon (2010, p. 23) envision that market studies scholarship can offer a space for experimentation that 'opens onto new forms of organization and theorization'; we might also be civilizing markets, envisioning other ways of organizing in response to the most pressing problems of today (Ossandón 2013). In doing so, we should allow others to hold us and our texts accountable for the effects they (help to) bring into being. We should be forthright about our own positionality. We do not suggest a reflexive pursuit of our writings for its own sake, a destructive deconstruction of the discipline. Instead we have offered a short reflexive excursus, turning our methodology upon ourselves, to highlight the potential of our texts as emancipatory engines. As Fourcade and Healy (2007, p. 305) suggest, 'theorists in economics, political science, and sociology [should] critically consider their own participation in the definition of the market's moral categories and in the construction of competing moralizing instruments and techniques'. By this we do not mean that we should seek to somehow measure the effects of our participation or of our critical interventions in the markets that we study. Those effects are rarely (if at all) transparent and 
straightforward, and performativity, as the field of market studies has shown, is riddled with conflicts, oppositions, and misfires. We hope that our work, through joining other agencies in performativity struggles, might be able to influence, to suggest, and to nudge the shaping of social worlds. Our critically engaged marketography may be fragile, complex and uncertain; nonetheless, we believe it is worth the risks.

Araujo, L., Finch, J. and Kjellberg, H., eds., 2010. Reconnecting Marketing to Markets. Oxford: Oxford University Press.

Austin, J., 1978. How to Do Things with Words. Oxford: Oxford University Press.

Battaglia, D., 1999. Towards an ethics of the open subject: writing culture in good conscience. In: Moore, H. L. ed. Anthropological Theory Today. Cambridge: Polity Press.

Beunza, D. and Ferraro, F. 2018. Performative Work: Bridging Performativity and Institutional Theory in the Responsible Investment Field. Organization Studies, 0(0), 0170840617747917.

Blackstock, K., et al. 2015. Participatory research to influence participatory governance: managing relationships with planners. Area, 47(3), 254-260.

Boldyrev, I. and Svetlova, E., 2016. After the Turn: How the Performativity of Economics Matters. In: Boldyrev, I. and Svetlova, E. eds. Enacting Dismal Science: New Perspectives on the Performativity of Economics. New York: Palgrave Macmillan US, 1-27.

Braun, K. and Könninger, S. 2017. From experiments to ecosystems? Reviewing public participation, scientific governance and the systemic turn. Public Understanding of Science, 0(0), 0963662517717375.

Bryan, D. and Rafferty, M. 2015. Decomposing Money: Ontological options and spreads. Journal of Cultural Economy, 1-16.

Butler, J. 2010. Performative Agency. Journal of Cultural Economy, 3(2), 147-161.

Çalışkan, K. and Callon, M. 2009. Economization, part 1: shifting attention from the economy towards processes of economization. Economy and Society, 38(3), 369 - 398.

Çalışkan, K. and Callon, M. 2010. Economization, part 2: a research programme for the study of markets. Economy and Society, 39(1), 1 - 32.

Callon, M., 1998. The embeddedness of economic markets in economics. In: Callon, M. ed. The Laws of the Markets. Oxford: Oxford University Press, 1-58.

Callon, M. and Muniesa, F. 2005. Peripheral Vision: Economic Markets as Calculative Collective Devices. Organization Studies, 26(8), 1229-1250.

Callon, M., Muniesa, F. and Millo, Y., 2007. Market devices. Oxford: Blackwell Publishers.

Christophers, B. 2014. From Marx to market and back again: Performing the economy. Geoforum, 57, $12-20$.

Clifford, J., 1992. Traveling Cultures. In: Grossberg, L., Nelson, C. and Treichler, P. A. eds. Cultural Studies. New York: Routledge, 96-117.

Cochoy, F. 2015. Myriam's 'adverteasing': on the performative power of marketing promises. Journal of Marketing Management, 31(1-2), 123-140.

Cochoy, F., Giraudeau, M. and McFall, L. 2010. Performativity, Economics and Politics. Journal of Cultural Economy, 3(2), 139-146.

Cunliffe, A. L. 2010. Retelling Tales of the Field: In Search of Organizational Ethnography 20 Years On. Organizational Research Methods, 13(2), 224-239. 
Denzin, N. K. 2006. Analytic Autoethnography, or Deja Vu all Over Again. Journal of Contemporary Ethnography, 35(4), 419-428.

Deville, J., 2017. The responsibilities of marketography. [online]. Available from: http://www.journalofculturaleconomy.org/the-responsibilities-of-marketography/.

du Gay, P. 2008. Max Weber and the Moral Economy of Office. Journal of Cultural Economy, 1(2), 129-144.

Du Gay, P. and Pryke, M., 2002. Cultural Economy: Cultural Analysis and Commercial Life. Sage.

Fourcade, M. and Healy, K. 2007. Moral Views of Market Society. Annual Review of Sociology, 33(1), 285-311.

Frankel, C., Ossandón, J. and Pallesen, T., 2015. Markets for Collective Concerns. EGOS Colloquium. Athens.

Friedman, M., 1966. The methodology of positive economics. Essays on positive economics. Chicago: University of Chicago Press.

Geiger, S. and Gross, N. 2018. Market Failures and Market Framings: Can a market be transformed from the inside? Organization Studies, 39(10), 1357-1376.

Gond, J.-P., et al. 2015. What do we mean by performativity in organisational and management theory? The uses and abuses of performativity. International Journal of Management Reviews, 00, 1-24.

Goodall, H. L. 2010. From Tales of the Field to tales of the Future. Organizational Research Methods, 13(2), 256-267.

Haraway, D. 1988. Situated knowledges: The science question in feminism and the privilege of partial perspective. Feminist Studies, 14(3), 575-599.

Haraway, D., 1992. The promises of monsters: a regenerative politics for inappropriate/d others. In: Grossberg, L., Nelson, C. and Treichler, P. A. eds. Cultural Studies. New York: Routledge, 295-337.

Hardie, I. and MacKenzie, D. 2007. Assembling an economic actor: The agencement of a hedge fund. The Sociological Review, 55(1), 57-80.

Helgesson, C.-F. and Muniesa, F. 2013. For what it's worth: An introduction to valuation studies. Valuation Studies, 1(1), 1-10.

Hine, C., 2000. Virtual Ethnography. London: Sage.

Hirschman, A. O., 1977. The Passions and the Interests. Princeton: Princeton University Press.

Latour, B., 2007. Reassembling the Social: An Introduction to Actor-Network-Theory (New Edition). Oxford: Oxford University Press.

Law, J. and Urry, J. 2004. Enacting the social. Economy and Society, 33(3), 390-410.

MacKenzie, D., 2006. An Engine, Not a Camera: How Financial Models Shape Markets. Cambridge: MIT Press.

MacKenzie, D., 2009. Material Markets: How Economic Agents are Constructed. Oxford: Oxford University Press.

MacKenzie, D. 2017. A Material Political Economy: Automated Trading Desk and Price Prediction in High-Frequency Trading. Social Studies of Science, 47(2), 172-194.

MacKenzie, D. and Millo, Y. 2003. Constructing a market, performing theory: the historical sociology of a financial derivatives exchange. American Journal of Sociology, 109(1), 107-145.

MacKenzie, D., Munesia, F. and Siu, L., eds., 2007. Do Economists Make Markets? On the Performativity of Economics. Princeton: Princeton University Press.

McFall, L. and Ossandón, J., 2014. What's new in the 'new, new economic sociology' and should organisation studies care? In: Adler, P., et al. eds. Oxford Handbook of Sociology, Social Theory and Organization Studies: Contemporary Currents. Oxford: Oxford University Press, 510-533.

Mol, A., 2002. The body multiple: Ontology in medical practice. Durham and London: Duke University Press.

Muniesa, F. 2011. A flank movement in the understanding of valuation. The Sociological Review, 59, 24-38.

Neyland, D., 2008. Organizational Ethnography. London: SAGE. 
Neyland, D., 2015. Challenges of Organizational Ethnography: reflecting on methodological insights. In: Dykes, F. and Flacking, R. eds. Ethnographic Research in Maternal and Child Health. London: Routledge.

Neyland, D. and Ehrenstein, V., 2017. Marketography: Ethnographies of markets [online]. Available from: http://www.marketproblems.com/marketography-2017.html.

Nik-Khah, E. and Mirowski, P., 2007. Markets made flesh: perfomativity, and a problem in science studies, augmented with a consideration of the FCC auctions. In: MacKenzie, D., Muniesa, F. and Siu, L. eds. Do economists make markets? Princeton: Princeton University Press, 190224.

Ossandón, J., 2013. Are markets matching Callon and Roth? [online]. Available from: http://www.charisma-network.net/markets/are-markets-matching-callon-and-roth\#_edn4 [Accessed 15 November 2017.

Ossandón, J. 2014. Reassembling and Cutting the Social with Health Insurance. Journal of Cultural Economy, 7(3), 291-307.

Pachirat, T., 2018. Among Wolves: Ethnography and the immersive study of power. New York: Routledge.

Palo, T., Mason, K. and Roscoe, P. 2018. Performing a Myth to Make a Market: The construction of the 'magical world' of Santa. Organization Studies, 0(0), 0170840618789192.

Poovey, M., 2008. Genres of the Credit Economy. Chicago: University of Chicago Press.

Preda, A., 2009. Framing finance: The boundaries of markets and modern capitalism. University of Chicago Press.

Roscoe, P., 2014. I Spend Therefore I Am. London: Penguin Viking.

Roscoe, P., 2015. A moral economy of transplantation: Competing regimes of value in the allocation of transplant organs. In Helgesson, C., Lee, F., \& Dussauge, I. eds. Value Practices in Life Sciences. Oxford: Oxford University Press, 99-118

Roscoe, P., 2017. The Rise and Fall of the Penny-Share Offer: a Historical Sociology of London's Smaller Company Markets. University of St Andrews.

Roscoe, P. and Chillas, S. 2014. The state of affairs: critical performativity and the online dating industry. Organization, 21(6), 797-820.

Safri, M. 2015. Mapping noncapitalist supply chains: Toward an alternate conception of value creation and distribution. Organization, 22(6), 924-941.

Shonkwiler, A. and La Berge, L. C., 2014. A theory of capitalist realism. In: Shonkwiler, A. and La Berge, L. C. eds. Reading capitalist realism. Iowa City: University of Iowa Press, 1-25.

Spicer, A., Alvesson, M. and Karreman, D. 2009. Critical performativity: The unfinished business of critical management studies. Human Relations, 62(4), 537-560.

Van Maanen, J., 1988. Tales of the Field Chicago: University of Chicago Press.

Watson, T. J. 2011. Ethnography, Reality, and Truth: The Vital Need for Studies of 'How Things Work' in Organizations and Managemen. Journal of Management Studies, 48, 202-217.

Yanow, D., 2009. Dear Author, Dear Reader: The Third Hermeneutic in Writing and Reviewing Ethnography. In: Schatz, E. ed. Political Ethnography: What immersion contributes to the study of power. Chicago: University of Chicago Press, 275-303. 